\title{
Physiological response of oil palm interspecific hybrids (Elaeis oleifera H.B.K. Cortes versus Elaeis guineensis Jacq.) to water deficit
}

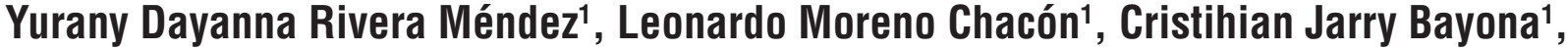 Hernán Mauricio Romero ${ }^{1,2 *}$}

\author{
${ }^{1}$ Biology and Breeding Program, Oil Palm Research Center, Cenipalma, Bogotá, Colombia. \\ ${ }^{2}$ Department of Biology, Universidad Nacional de Colombia, Bogotá, Colombia. \\ *Corresponding author: hromero@cenipalma.org
}

Received: 31 October 2012; Accepted: 17 January 2013

\begin{abstract}
Water supply is the main yield-limiting abiotic factor of oil palm in Colombia. To determine the effect of water deficit on the physiology of oil palm and to assess the tolerance degree to this condition, interspecific Elaeis oleifera versus Elaeis guineensis 'U1273', 'U1859', 'U1914', and 'U1937' hybrids were planted for 60 days in soil with different water potentials $(-0.042,-0.5,-1.0$, and $-2.0 \mathrm{MPa})$ in a complete randomized factorial design with three replications. The water potential, osmotic adjustment molecules (total and reducing sugar content), gas exchange (photosynthesis rate, stomatal conductance, water use efficiency, and leaf respiration), and vegetative growth (height, bulb diameter, leaf area, number of leaves, total dry matter, and assimilate partitioning between roots and aerial parts) were measured. Soil water potential had a significant effect on the ecophysiological response of the hybrids. At $-2 \mathrm{MPa}$, there was practically no carbon dioxide assimilation. Under optimal moisture conditions, the 'U1859' hybrid recorded the highest photosynthetic rate and the lowest respiratory rate, while under moderate and severe water deficits, the 'U1937' hybrid showed the highest photosynthetic rate, the lowest respiratory rate, moved its assimilates mainly towards the roots, and was the only one to adjust its water potential (active accumulation of sugars). Two environment/genotype tolerance relationships were established based on high photosynthetic rate, low leaf respiration rate, water potential adjustment, water use efficiency under adequate moisture conditions ('U1859’>'U1937'='U1914’>'U1273'), and under water deficit ('U1937’>'U1914'>'U1859’>'U1273').
\end{abstract}

Keywords: ecophysiology, growth, stress, tolerance, water potential.

\section{INTRODUCTION}

Water supply is the main yield-limiting factor of oil palm (Kallarackal et al., 2004). There are large cultivated areas worldwide, which lack optimal conditions in terms of water availability, and the direct result is the yield reduction in terms of production of fresh fruit bunches and oil (Cornaire et al., 1994). Three of the four oil palm-growing regions in Colombia suffer from poor water availability, with prolonged dry periods of more than four months in the Central and Eastern Zones and up to eight in the North one (Romero et al., 2007). With the exception of the Western zone, these periods may affect oil palm production, given the variation in the proportion of male and female inflorescences (Corley and Tinker, 2003).

Irrigation systems for large areas, in order to prevent or reduce the effects of water stress on oil palm, have both economic and technical limitations (Cayón, 1998). Therefore, the detection of differences in oil palm behavior under drought conditions, according to their genetic origin and type of cross, partially independent of their production potential, means that genetics is the best alternative to 
identify high-performing crosses and parents (Cornaire et al., 1994). Drought tolerance does not depend on a single physiological trait, but on the relative contribution of several tolerance mechanisms that can operate at different stages of a plant development (Jaleel et al., 2009), such as stomatal conductance during the dry season, photosynthetic potential, root system, osmotic adjustment, and reserves of assimilates (Smith, 1989; Villalobos et al., 1990; Martínez and Moreno, 1992; Cayón, 1998; Nieto et al., 2009).

The interspecific hybrid Elaeis oleifera versus Elaeis guineensis (OXG) has gained importance in the Latin American oil palm industry, as it exhibits characteristics of agronomic interest that have high potential to improve the competitiveness and sustainability of the crop, such as the partial resistance to bud rot disease (Torres et al., 2010) that is perhaps the major threat to oil palm industry in the Americas. Besides that, the hybrid presents better oil composition in terms of antioxidant concentrations and iodine index (Corley and Tinker, 2003; Rocha et al., 2006).

Therefore, this research sought to find the ecophysiological response of oil palm hybrids to water deficit, and to identify which hybrids perform better under water deficit conditions (tolerance).

\section{MATERIAL AND METHODS}

The study was carried out in a mesh house in the Palmar de La Vizcaína Experimental Field, Barrancabermeja- Santander (Colombia), at a 125-meter altitude above the sea level, with an average temperature of $34^{\circ} \mathrm{C}$, a $70.5 \%$ relative humidity, an annual rainfall of $3,852 \mathrm{~mm}$, under tropical rainforest agroecological conditions tropical rainforest agroecological conditions (Holdridge life zones system).

Four oil palm interspecific hybrids were used: 'U1273' (Oleífera versus M0.NF), 'U1859' (Oleífera versus AV.DJ), 'U1914' (Oleífera versus M0), and 'U1937' (Oleífera versus C.MIX). They were under four soil water potentials: $-0.042 \mathrm{MPa}$ (field capacity), $-0.5 \mathrm{MPa}$ (moderate water deficit), -1.0 MPa (severe water deficit), and -2.0 MPa (very severe water deficit) in a complete randomized design in factorial arrangement $(4 \times 4)$, with three replications. The experimental unit consisted of three palms.

Seedlings with the second lanceolate leaf fully opened, stage 112 (Hormaza et al., 2012), were kept at field capacity for one month before being subjected to different soil water potentials in a 60-day period. The depth of irrigation to be applied in each water potential was calculated taking into account the effective root depth, physical characteristics of the soil (texture, apparent density, and moisture retention curve), and soil moisture was monitored daily with a SM-200 soil moisture sensor (DELTA-T, Cambridge, the United Kingdom) attached to the manual $\mathrm{HH} 2$ datalogger (DELTA-T, Cambridge, the United Kingdom). The field capacity was measured on a dry basis, and its equivalence to water potential was set at $-0.042 \mathrm{MPa}$.

After 60 days, vegetative growth variables were recorded: height, bulb diameter, leaf area, number of leaves, total dry matter, and assimilate partitioning between roots and aerial parts. Height of the bulb, from the root insertion point up to the petiole insertion point, and the diameter of the thickest part of the stem were measured with a gauge. For the number of leaves, the amount of fully expanded leaves present at the time of sampling was counted. Roots and aerial parts were separated to determine the dry weight of the entire plant and to establish its coefficient (aerial or root parts). They were washed with distilled water and oven-dried at $105^{\circ} \mathrm{C}$ for 24 hours (later the mass was constant), and the dry weight was determined with an electronic scale and recorded. Before drying, the leaf area of each seedling was determined using a LI-3100 scanner (LICOR Inc, Nebraska, USA).

Gas exchange (photosynthesis rate, stomatal conductance, water use efficiency, and leaf respiration) measurements were conducted on leaf number three from 8:30 to $11: 00 \mathrm{~h}$, using the LI-6400XT open-path portable photosynthesis system (LICOR Inc, Nebraska, the USA). For these determinations, leaf temperature was kept constant at $30^{\circ} \mathrm{C}, \mathrm{CO}_{2}$ concentration in the chamber at $400 \mu \mathrm{mol} \mathrm{mol}^{-1}$, saturation water vapor pressure at $2.5 \mathrm{kPa}$, and a maximum coefficient of variation (CV) of $3 \%$. The "light curve" routine for photosynthesis rate was used at thirteen levels of photosynthetic photon flux density (PPFD: 0, 20, 50, 150, 300, 500, 800, 1,000, 1,200, $1,400,1,600,1,800$ and $2,000 \mu \mathrm{mol}$ photon $\left.\mathrm{m}^{-2} \mathrm{~s}^{-1}\right)$. in a decreasing order. The resulting curves were fitted with the Statistix ${ }^{\circledast} 9.0$ analytical software to the Michaelis Menten hyperbolic model:

$A_{n}=\left[\left(A_{\max } x P P F D\right) /(b+P P F D)\right]-R d$,

where,

$A_{n}$ : rate of net photosynthesis $\left(\mu \mathrm{mol} \mathrm{CO} \mathrm{m}_{2} \mathrm{~m}^{-1}\right)$,

$A_{\text {max }}$ : irradiance-saturated rate of gross photosynthesis $\left(\mu \mathrm{mol} \mathrm{CO}{ }_{2} \mathrm{~m}^{-2} \mathrm{~s}^{-1}\right)$,

b: $1 / 2$ of saturating PPFD $\left(\mu \mathrm{mol}\right.$ photon $\left.\mathrm{m}^{-2} \mathrm{~s}^{-1}\right)$, and

$\mathrm{Rd}$ : dark respiration rate $\left(\mu \mathrm{mol} \mathrm{CO}_{2} \mathrm{~m}^{-2} \mathrm{~s}^{-1}\right)$, corresponding to the value of $A_{n}$ when PPFD equals 0 ( $\mu$ mol photon $\mathrm{m}^{-2} \mathrm{~s}^{-1}$ ). 
Light compensation point (LCP) was the value of PPFD which there was no net carbon assimilation. The quantum yield of photosynthesis $(\Phi)$ was estimated by the linear regression of $A$ to PPFD $<300 \mu \mathrm{mol}$ photon $\mathrm{m}^{-2} \mathrm{~s}^{-1}$, in the linear equation, $\Phi$ is the coefficient of the independent term (slope of the curve). The Michaelis Menten hyperbolic model showed good correlation with the measured photosynthetic parameters (higher coefficient of determination, $\mathrm{R}^{2}$, and lower error mean square); it estimated a more realistic light-saturated rate and the apparent quantum yield of photosynthesis (unshown data). Also, Gomes et al. (2006) pointed out that this model allowed understanding the links between productivity and climatic factors in oil palm. However, the parameters 'b' and 'Rd' were not analyzed in this study.

Leaf respiration and leaf water potential were measured at pre-dawn, the first using the LI-6400XT, and the latter with the Scholander type pressure chamber pump-up model (PMS Instrument Company, Oregon, the USA) - pre-assessments stipulated that this time frame clearly shows the effect of the treatments.

For quantifying the osmotic adjustment molecules (total sugar content - TSC and reducing sugar content $\mathrm{RSC}$ ), tissue from leaf number three was directly cut and stored at $-80^{\circ} \mathrm{C}$, then it was macerated (without midribs) with liquid nitrogen until a fine powder was obtained, which was kept at $-80^{\circ} \mathrm{C}$ up until its final treatment. TSC and RSC were performed on a $15 \mathrm{mg}$ fresh leaf tissue using spectrophotometric methods (TSC - Dubois et al., 1956; RSC - Nelson, 1944 and Somogyi, 1952).
The created data were subjected to an analysis of variance, and the mean comparison was made by Tukey's test, using the SAS statistical software ${ }^{\circledR}$ version 9.1 (SAS Institute Inc., North Carolina, the USA).

\section{RESULTS}

In general, there was a significant effect of the soil water potential on the ecophysiological response of OxG hybrids after two months. Additionally, leaf water potential, osmotic adjustment molecules (total sugar content and reducing sugar content), assimilate partitioning, and

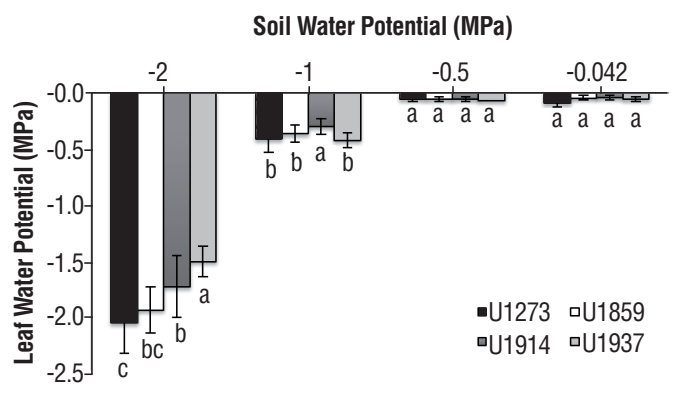

Figure 1. Average \pm 1 standard deviation of leaflet water potential (MPa) at pre-dawn of OxG hybrids subjected to different soil water potentials for two months (averages with different letters are significantly different, $p<0.05$ - Tukey).

Table 1. Gas exchange variables of OxG hybrids subjected to different soil water potentials for two months. Variables in which water potential vs. genotype interaction was significant are shown.

\begin{tabular}{|c|c|c|c|c|}
\hline \multirow{2}{*}{ Hybrid } & \multicolumn{4}{|c|}{ Water potential (MPa) } \\
\hline & -2.0 & -1.0 & -0.5 & -0.042 \\
\hline \multicolumn{5}{|c|}{ Maximum photosynthesis $\left(\mu \mathrm{mol} \mathrm{CO}_{2} \mathrm{~m}^{-2} \mathrm{~s}^{-1}\right)$} \\
\hline U1273 & $0.2 \pm 0.0 \mathrm{c}$ & $0.4 \pm 0.1 \mathrm{c}$ & $6.2 \pm 0.1 \mathrm{~b}$ & $15.4 \pm 1.8 \mathrm{~b}$ \\
\hline U1859 & $0.7 \pm 0.2 b$ & $1.7 \pm 0.1 b$ & $6.1 \pm 0.6 b$ & $17.6 \pm 0.9 \mathrm{a}$ \\
\hline U1914 & $1.3 \pm 0.4 \mathrm{a}$ & $1.1 \pm 0.1 b$ & $4.5 \pm 0.5 \mathrm{c}$ & $9.2 \pm 0.2 d$ \\
\hline U1937 & $1.1 \pm 0.1 \mathrm{a}$ & $3.9 \pm 0.1 \mathrm{a}$ & $8.5 \pm 0.4 \mathrm{a}$ & $12.7 \pm 0.2 \mathrm{c}$ \\
\hline \multicolumn{5}{|c|}{ Quantum yield of photosynthesis ( $\mu \mathrm{mol} \mathrm{CO}_{2} \mathrm{~mol}^{-1}$ photons) } \\
\hline U1273 & $0.4 \pm 0.1 \mathrm{c}$ & $0.8 \pm 0.2 \mathrm{c}$ & $4.4 \pm 0.1 \mathrm{c}$ & $21.0 \pm 2.4 \mathrm{~b}$ \\
\hline U1859 & $0.7 \pm 0.2 b$ & $3.5 \pm 0.2 b$ & $13.5 \pm 1.3 \mathrm{a}$ & $28.9 \pm 1.5 \mathrm{a}$ \\
\hline U1914 & $2.3 \pm 0.7 \mathrm{a}$ & $2.6 \pm 0.2 b$ & $7.0 \pm 0.8 \mathrm{~b}$ & $15.2 \pm 0.4 \mathrm{c}$ \\
\hline U1937 & $2.7 \pm 0.3 \mathrm{a}$ & $9.1 \pm 0.1 \mathrm{a}$ & $13.8 \pm 0.6 \mathrm{a}$ & $21.4 \pm 0.4 \mathrm{~b}$ \\
\hline \multicolumn{5}{|c|}{ Light compensation point $\left(\mu \mathrm{mol}\right.$ photons $\left.\mathrm{m}^{-2} \mathrm{~s}^{-1}\right)$} \\
\hline U1273 & $105.6 \pm 20.8 b$ & $14.3 \pm 2.7 \mathrm{c}$ & $11.9 \pm 0.2 b$ & $2.7 \pm 0.3 c$ \\
\hline U1859 & $201.3 \pm 52.7 \mathrm{a}$ & $28.0 \pm 1.8 \mathrm{a}$ & $2.9 \pm 0.3 \mathrm{c}$ & $3.9 \pm 0.2 \mathrm{~b}$ \\
\hline U1914 & $31.5 \pm 9.1 \mathrm{c}$ & $23.4 \pm 2.2 \mathrm{~b}$ & $19.9 \pm 2.3 \mathrm{a}$ & $13.8 \pm 0.3 \mathrm{a}$ \\
\hline U1937 & $32.2 \pm 3.8 \mathrm{c}$ & $1.7 \pm 0.0 \mathrm{~d}$ & $1.2 \pm 0.1 \mathrm{~d}$ & $0.8 \pm 0.0 \mathrm{~d}$ \\
\hline \multicolumn{5}{|c|}{ Water use efficiency $\left(\mathrm{mmol} \mathrm{CO}_{2} \mathrm{mmol}^{-1} \mathrm{H}_{2} \mathrm{O}\right)$} \\
\hline U1273 & $(2.0 \pm 0.5) \mathrm{E}-04 \mathrm{~b}$ & $(3.2 \pm 0.3) \mathrm{E}-03 \mathrm{~b}$ & $(3.2 \pm 0.3) \mathrm{E}-03 \mathrm{~b}$ & $(2.9 \pm 0.4) \mathrm{E}-03 \mathrm{a}$ \\
\hline U1859 & $(1.1 \pm 0.5) \mathrm{E}-03 \mathrm{a}$ & $(3.2 \pm 0.2) E-03 b$ & $(3.3 \pm 0.2) \mathrm{E}-03 \mathrm{~b}$ & $(3.1 \pm 0.2) \mathrm{E}-03 \mathrm{a}$ \\
\hline U1914 & $(1.3 \pm 0.1) \mathrm{E}-03 \mathrm{a}$ & $(3.6 \pm 0.1) \mathrm{E}-03 \mathrm{a}$ & $(3.5 \pm 0.4) \mathrm{E}-03 \mathrm{a}$ & $(3.1 \pm 0.2) \mathrm{E}-03 \mathrm{a}$ \\
\hline U1937 & $(1.2 \pm 0.1) \mathrm{E}-03 \mathrm{a}$ & $(3.4 \pm 0.2) \mathrm{E}-03 \mathrm{a}$ & $(3.5 \pm 0.3) \mathrm{E}-03 \mathrm{a}$ & $(3.1 \pm 0.3) \mathrm{E}-03 \mathrm{a}$ \\
\hline
\end{tabular}

Averages with different letters are significantly different, $p<0.05$ (Tukey) 
gas exchange (maximum photosynthesis, quantum yield of photosynthesis, light compensation point, water use efficiency and leaf respiration) variables showed significant differences $(p<0.05)$ due to the origin of the hybrids and their interaction (Figure 1, Tables 1 and 2); while vegetative growth variables (bulb diameter, leaf area, total dry weight, height and leaf number) and stomatal conductance were not affected by the interaction origin of the hybrids vs. soil water potential (Table 3 ).

Water potential and osmotic adjustment: Figure 1 shows the water potential at pre-dawn of leaves of $0 \times G$ hybrids subjected to different soil water potentials for two months. At this time, leaf water potential reached their maximum value (less negative), because the evaporative demand of the atmosphere was minimum and the soil moisture content was higher. Under an atmospheric potential of $-30 \pm 5 \mathrm{MPa}$, the water potential of the palms became more negative as the soil water potential increased, and there was a significantly differential response among $0 \times G$ hybrids. Under field capacity and moderate water deficit conditions, the water potential of the hybrids was practically similar, while treatments with higher water deficit (-1.0 and -2.0 MPa) created pressure on the water potential of the palms. Therefore, the 'U1937' and 'U1914' ones adjusted their water potential to maintain the water flow and conserve their water status through some osmotic adjustment mechanism. Indeed, there was an active accumulation of leaf reducing and total sugars, in response to two months of water deficit, which is in line with an osmotic adjustment mechanism (Table 2). Under a moderate water deficit (-0.5 MPa), the 'U1859' hybrid decreased its osmotic potential by increasing the levels of reducing sugars, while under severe (and even very severe) water deficit (-1.0 and $-2.0 \mathrm{MPa}$ ) the 'U1937' hybrid accumulated both solutes.

Table 2. Leaf respiration, assimilate partitioning and osmotic adjustment variables of OxG hybrids subjected to different soil water potentials for two months. Variables in which water potential vs. genotype interaction was significant are shown.

\begin{tabular}{|c|c|c|c|c|}
\hline \multirow{2}{*}{ Hybrid } & \multicolumn{4}{|c|}{ Water potential (MPa) } \\
\hline & -2.0 & -1.0 & -0.5 & -0.042 \\
\hline \multicolumn{5}{|c|}{ Leaf respiration $\left(\mu \mathrm{mol} \mathrm{CO}_{2} \mathrm{~m}^{-2} \mathrm{~s}^{-1}\right)$} \\
\hline U1273 & $0.39 \pm 0.01 b$ & $0.63 \pm 0.01 \mathrm{a}$ & $0.93 \pm 0.02 \mathrm{a}$ & $1.17 \pm 0.05 \mathrm{a}$ \\
\hline U1859 & $0.89 \pm 0.04 \mathrm{a}$ & $0.73 \pm 0.06 \mathrm{a}$ & $0.75 \pm 0.01 b$ & $0.49 \pm 0.01 \mathrm{c}$ \\
\hline U1914 & $0.46 \pm 0.00 \mathrm{~b}$ & $0.72 \pm 0.00 \mathrm{a}$ & $0.75 \pm 0.13 b$ & $0.79 \pm 0.06 \mathrm{~b}$ \\
\hline U1937 & $0.16 \pm 0.04 \mathrm{c}$ & $0.52 \pm 0.04 b$ & $0.69 \pm 0.14 b$ & $1.16 \pm 0.05 \mathrm{a}$ \\
\hline \multicolumn{5}{|c|}{ Assimilate partitioning } \\
\hline U1273 & $3.8 \pm 0.6 \mathrm{~b}$ & $3.1 \pm 0.5 b$ & $3.1 \pm 0.6 \mathrm{ab}$ & $3.0 \pm 0.8 \mathrm{a}$ \\
\hline U1859 & $3.7 \pm 0.5 b$ & $4.0 \pm 1.0 \mathrm{a}$ & $3.5 \pm 0.7 \mathrm{a}$ & $2.5 \pm 0.7 b$ \\
\hline U1914 & $5.4 \pm 1.1 \mathrm{a}$ & $3.9 \pm 0.7 \mathrm{a}$ & $2.8 \pm 0.1 \mathrm{~b}$ & $1.7 \pm 0.4 \mathrm{c}$ \\
\hline U1937 & $3.2 \pm 0.8 \mathrm{c}$ & $3.0 \pm 0.7 \mathrm{~b}$ & $2.3 \pm 0.1 \mathrm{c}$ & $2.2 \pm 0.1 \mathrm{~b}$ \\
\hline \multicolumn{5}{|c|}{ Reducing sugar content (mg sugar g-1 FLT) } \\
\hline U1273 & $17.93 \pm 1.18 b$ & $8.71 \pm 1.59 a b$ & $8.67 \pm 2.41 \mathrm{~b}$ & $2.37 \pm 0.32 b$ \\
\hline U1859 & $18.38 \pm 1.56 b$ & $7.07 \pm 0.54 \mathrm{~b}$ & $10.81 \pm 1.14 \mathrm{a}$ & $2.39 \pm 0.51 \mathrm{a}$ \\
\hline U1914 & $19.68 \pm 3.31 \mathrm{ab}$ & $8.61 \pm 0.95 a b$ & $8.78 \pm 0.73 b$ & $2.83 \pm 0.59 \mathrm{a}$ \\
\hline U1937 & $24.29 \pm 2.57 \mathrm{a}$ & $9.52 \pm 1.12 \mathrm{a}$ & $8.88 \pm 1.74 b$ & $3.77 \pm 0.78 \mathrm{a}$ \\
\hline \multicolumn{5}{|c|}{ Total sugar content (mg sugar g-1 FLT) } \\
\hline U1273 & $105.39 \pm 9.27 b$ & $45.06 \pm 3.04 b$ & $22.60 \pm 3.43 \mathrm{a}$ & $26.66 \pm 3.92 \mathrm{a}$ \\
\hline U1859 & $107.13 \pm 11.54 \mathrm{~b}$ & $52.63 \pm 4.45 b$ & $23.39 \pm 2.28 \mathrm{a}$ & $13.10 \pm 3.00 b$ \\
\hline U1914 & $117.78 \pm 21.34 b$ & $40.26 \pm 4.51 b$ & $25.71 \pm 3.86 \mathrm{a}$ & $15.93 \pm 2.70 b$ \\
\hline U1937 & $149.50 \pm 13.03 \mathrm{a}$ & $56.65 \pm 3.05 \mathrm{a}$ & $22.52 \pm 4.45 \mathrm{a}$ & $13.84 \pm 1.30 b$ \\
\hline
\end{tabular}

Averages with different letters are significantly different, $p<0.05$ (Tukey); FLT: fresh leaf tissue.

Table 3. Physiological variables of OxG hybrids subjected to different soil water potentials for two months. Variables in which water potential versus genotype interaction was not significant are shown.

\begin{tabular}{|c|c|c|c|c|c|c|c|}
\hline Factor & Variable & Bulb diameter (cm) & Leaf area $\left(\mathrm{cm}^{2}\right)$ & Total dry matter (g) & Height (cm) & Leaf number & $\begin{array}{c}\text { Stomatal conductance } \\
\left(\mathrm{mmol} \mathrm{H}_{2} \mathrm{O} \mathrm{m}^{-2} \mathrm{~s}^{-1}\right)\end{array}$ \\
\hline \multirow{4}{*}{ Hybrid } & U1273 & $48.2 \mathrm{a}$ & $3,954.2 \mathrm{a}$ & $125.2 \mathrm{a}$ & $108.0 \mathrm{a}$ & $11.6 \mathrm{a}$ & $132.3 \mathrm{ab}$ \\
\hline & U1859 & $47.4 \mathrm{a}$ & $3,491.7 \mathrm{a}$ & $116.3 \mathrm{a}$ & $91.7 \mathrm{~b}$ & $10.6 \mathrm{~b}$ & $168.8 \mathrm{a}$ \\
\hline & U1914 & $47.7 \mathrm{a}$ & $3,895.4 \mathrm{a}$ & $126.2 \mathrm{a}$ & $107.6 \mathrm{a}$ & $10.9 b$ & $118.9 \mathrm{~b}$ \\
\hline & U1937 & $48.1 \mathrm{a}$ & $3,571.5 \mathrm{a}$ & $118.6 \mathrm{a}$ & $93.7 \mathrm{~b}$ & $10.7 \mathrm{~b}$ & $148.9 \mathrm{ab}$ \\
\hline \multirow{4}{*}{$\begin{array}{l}\text { Water } \\
\text { potential } \\
\text { (MPa) }\end{array}$} & -2.0 & $32.9 \mathrm{~d}$ & $1,181.7 \mathrm{~d}$ & $40.9 \mathrm{~d}$ & $66.3 \mathrm{~d}$ & $10.0 \mathrm{~d}$ & $11.1 \mathrm{c}$ \\
\hline & -1.0 & $44.5 \mathrm{c}$ & $3,029.7 \mathrm{c}$ & $95.6 \mathrm{c}$ & $95.9 \mathrm{c}$ & $10.6 \mathrm{c}$ & $147.3 \mathrm{~b}$ \\
\hline & -0.5 & $52.4 \mathrm{~b}$ & $4,407.3 \mathrm{~b}$ & $137.6 \mathrm{~b}$ & $108.5 \mathrm{~b}$ & $11.5 b$ & $166.8 \mathrm{~b}$ \\
\hline & -0.042 & $61.5 \mathrm{a}$ & $6,294.0 \mathrm{a}$ & $212.0 \mathrm{a}$ & $130.3 \mathrm{a}$ & $11.8 \mathrm{a}$ & $243.6 \mathrm{a}$ \\
\hline
\end{tabular}

Averages with different letters are significantly different, $p<0.05$ (Tukey). 
Vegetative growth: Growth of the aerial part was reduced as the soil water potential increased, in order that under field capacity the increase in size, volume or weight, dependent on cell division and expansion, was higher, and at $-2.0 \mathrm{MPa}$ it showed the lowest values. Bulb diameter, leaf area, and total dry weight of OxG hybrids were similar under the same water potential, despite the fact that these variables were the most sensitive to water deficit. Thus, for all OxG hybrids under field capacity conditions and water potentials of -0.5 , $-1.0,-2.0 \mathrm{MPa}$, the bulb diameter decreased on average by 15,25 , and $48 \%$ respectively, while the total dry weight and leaf area decreased on average by 35,100 , and $440 \%$ respectively. Growth in terms of height and number of leaves was statistically different among hybrids independently of the soil moisture content (Table 3). The 'U1273' hybrid showed the greatest height and production of leaves. Also, all of those at -1.0 and $-2.0 \mathrm{MPa}$ had accumulation of nonexpanded "spear leaves" or new ones. The proportion of assimilates towards the aerial part of the plant was superior as the water deficit increased (Table 2). However, the response of hybrids was differential: assimilate partitioning of 'U1914' was the most affected by soil water potential (linear response), while 'U1273' and 'U1937' showed no significant variation. 'U1937' had the lowest partitioning ratio under water deficit, diverting its photoassimilates mainly towards the roots.

Gas exchange: The stomatal conductance did not show the effect of the genotype/water potential interaction (Table 3), which suggests that the stomata of OxG hybrids had a different regulation of water vapor losses and of carbon dioxide absorption regardless of soil moisture conditions. Thus, the 'U1859' hybrid had the highest gas exchange rates, and the 'U1914' one presented the lowest response both under adequate moisture conditions or very severe water deficit. Water use efficiency (WUE) calculated at the time of the highest gas exchange for photosynthesis and transpiration (8:30 to 11:00 hours) showed that under higher water deficit $(-2 \mathrm{MPa})$, all hybrids had a restriction on the stomatal opening for gas exchange, being hybrid 'U1273' the most sensitive. In treatments under moderate and severe water deficits (-0.5 and -1.0 MPa), 'U1914' and 'U1937' presented lower water consumption associated with the photosynthesis. Hence, both hybrids were able to maintain $\mathrm{CO}_{2}$ fixation with low water consumption (Table 1), i.e., they used efficiently the little water available in the soil for photosynthesis even under severe water deficit conditions. Finally, these hybrids showed two leaf respiration trends: the 'U1273', 'U1914', and 'U1937' had less consumption of the $\mathrm{CO}_{2}$ assimilated as the water deficit increased, while the leaf respiration rate of the 'U1859' hybrid was higher as the soil water potential increased, i.e., its leaf respiration rate was lower under optimal water conditions; therefore, at $-2 \mathrm{MPa}$ potential, its respiration rate was approximately five times higher than the consumption made by the 'U1937'(Table 2).
The response of all hybrids to water deficit described a curve where the photosynthetic rates are lower at low PPFD intensities, and increase progressively as the PPFD increases until reach the maximum values or light saturation point (Figure 2). Its initial gradient is the quantum yield of photosynthesis or the photosynthetic efficiency based on the absorbed photons, and the summit of the curve is the point of maximum photosynthesis of the genotype. Maximum photosynthesis $\left(A_{\text {max }}\right)$, light compensation point (LCP), and the quantum yield of photosynthesis $(\Phi)$ of $0 \times G$ hybrids subjected to different soil water potentials for two months were dependent upon the soil moisture regime (Table 1). In general, at $-0.5,-1.0 \mathrm{MPa}, \mathrm{A}_{\max }$ was observed at a lower PPFD and was one half and one-fourth of the maximum photosynthesis reached at field capacity. Under the most severe water deficit treatment $(-2 \mathrm{MPa})$, there was practically no carbon dioxide assimilation. Therefore, under optimal soil moisture conditions, the 'U1859' hybrid showed the highest $\Phi$ and photosynthetic rates significantly higher than those of the rest of the hybrids, even under low levels of PPFD, and maintained maximum photosynthetic rate in a wide range of PPFD, while the 'U1937' one presented the highest consumption of $\mathrm{CO}_{2}$ under moderate and severe water deficits $(-0.5,-1.0$, and -2.0 $\mathrm{MPa}$ ), saturated at higher PPFD values and used the intercepted energy for photosynthesis more efficiently. The LCP was directly proportional to the soil water potential; therefore at -2.0 $\mathrm{MPa}$, the PPFD under which the net exchange of $\mathrm{CO}_{2}$ of the leaf became zero was higher than that recorded under severe or moderate water deficit and field capacity. Under optimal soil moisture conditions, hybrids required minimal light stimulus to initiate the photosynthetic processes, especially the 'U1937', which demonstrated low compensation point values under water deficit, i.e., its photosynthesis was quickly offset by a low leaf respiration rate.

\section{DISCUSSION}

The values of the rate of photosynthesis, stomatal conductance, and leaf water potential observed under optimal water status and water deficit were similar to those found by Haniff (2006) and Kallarackal et al. (2004), who worked with attached and excised oil palm fronds from three Indian sites with a prolonged dry season, respectively.

Water deficit had a marked effect on the photosynthetic capacity of $0 \times G$ hybrids, and their plasticity to environmental conditions was mainly determined by the soil water potential. Thus, in terms of water deficit, the photosynthetic rate and transpiration decreased considerably, as pointed out by several authors (Smith, 1989; Martínez and Moreno, 1992; Prieto et al., 2004; Romero et al., 2007; Moreno, 2009; Cha et al., 2010), due mainly to stomatal closure that inhibits 

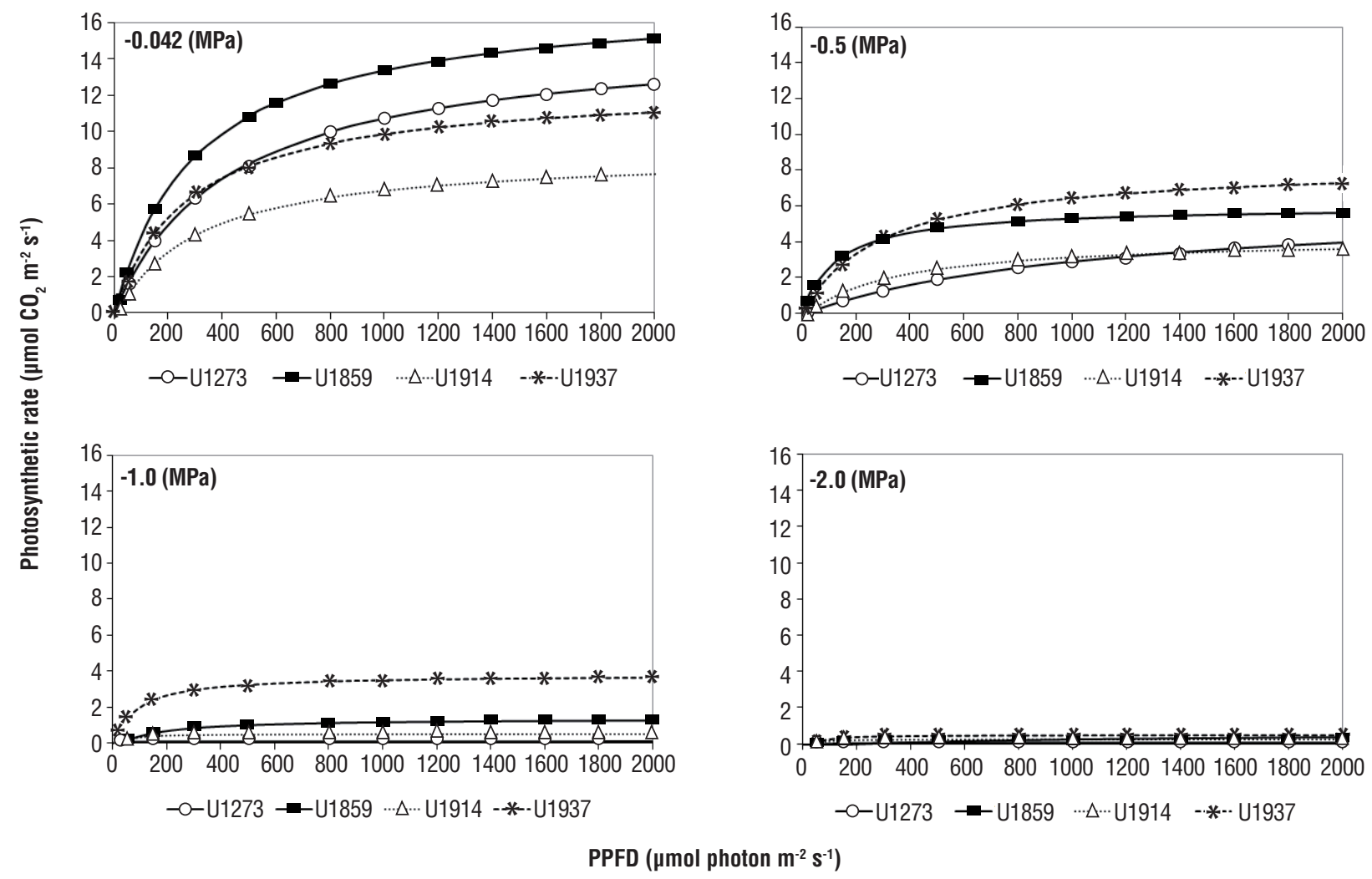

Figure 2. Photosynthetic response of $0 \times G$ hybrids to the photosynthetic photon flux density (PPFD) subjected to different soil water potentials for two months. The legend under the plots corresponds to the different hybrids used.

the diffusion of $\mathrm{CO}_{2}$ into the leaf and decreases its level (Ramachandra et al., 2004; Haniff, 2006).

The response of $0 x G$ hybrids was a differential and was dependent upon the soil moisture regime (Figure 3). Under optimal water conditions, the 'U1859' hybrid had the maximum production of photoassimilates through photosynthesis, while in the 'U1937' and 'U1914' ones, the physiological processes that regulate and are directly involved in growth (photosynthesis, WUE) were higher under water deficit. Therefore, it can be said that 'U1859' has a photosynthetic apparatus that would allow $\mathrm{CO}_{2}$ to be assimilated in an environment without water limitations, and 'U1937' and 'U1914' have a high photosynthetic capacity as they showed higher efficiency in the assimilation of $\mathrm{CO}_{2}$ under moderate to severe water deficit conditions, as reported by Smith (1993) and Pelaéz et al. (2010).

Since leaflets are the organs that contribute most to the losses by total respiration, i.e., 4 to $5 \%$ of gross assimilation in growth respiration and 33 to $34 \%$ in maintenance respiration (Henson, 1992), it could be expected that under adequate water conditions, without affecting the total assimilation of the plant, the 'U1859' hybrid, which maintained low leaf respiration rates, would have higher production of dry matter, while the 'U1937' would do the same under water deficit. However, the total dry weight, and in general, the vegetative growth were reduced as the soil water potential increased, as Cha et al. (2010) found when working with oil palm seedlings under water deficit conditions. This happens mainly due to a reduction in cellular division and expansion (Avendaño et al., 2008; Jaleel et al., 2009), and it showed no significant differences among the hybrids, but variances were observed in the assimilate partitioning between the aerial and root parts. The latter suggests that the conversion of carbohydrates into chemical energy was similar in all of them, while the 'U1937' hybrid was more efficient (more dry matter with less water consumption) in the distribution of photoassimilates towards the roots, which are necessary for vegetative growth and maintenance of the plant in a water-constrained environment (López et al., 2009; Moreno, 2009; García et al., 2010). Thus, increasing root absorption capacity per surface unit to favor the partitioning of assimilates towards this organ is a tolerance response to water deficit (Ryser, 2006; Polanía et al., 2009), mainly in oil palm (Sun et al., 2011). 

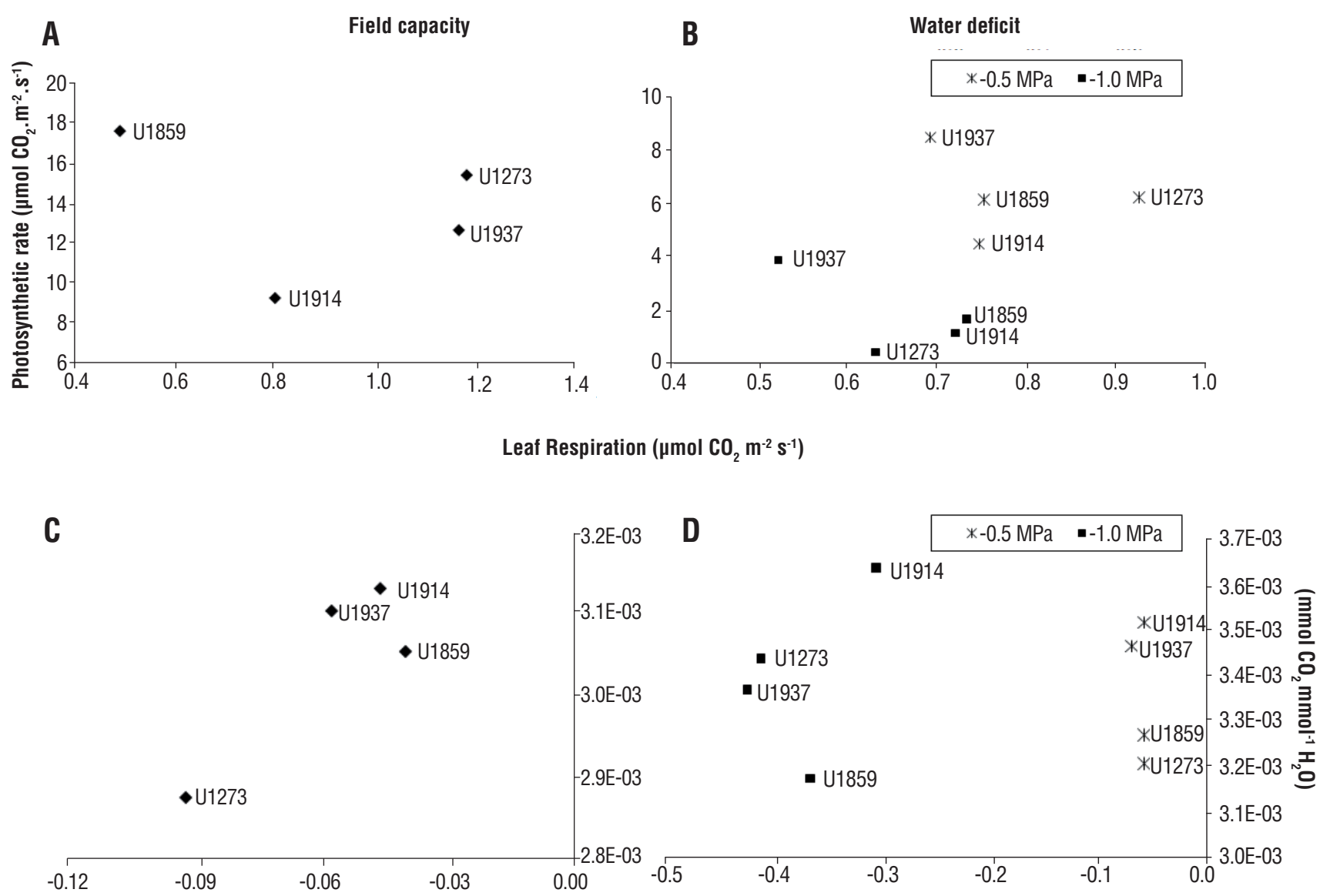

Leaf water potential (MPa)

Figure 3. Performance of $0 \times G$ hybrids subjected to field capacity, and moderate to severe water deficit conditions to some matched physiological variables. (A) and (B) Photosynthetic rate vs Leaf respiration; (C) and (D) Water Use Efficiency (WUE) vs Leaf Water Potential (LWP). (A) and (C) correspond to plants under field capacity, while (B) and (D) correspond to plants under moderate (-1.0 MPa) and severe (-2.0 MPa) water deficit.

However, under severe water deficit conditions, the 'U1937' hybrid decreased its overall water potential, as an active response to the accumulation of reducing and total sugars in leaf cells (decrease in osmotic potential), which allowed the plants to maintain their flow of water through the roots and reduce its loss through the stomatal chamber, a response that some authors consider as an indicator of growth or survival (tolerance) to water deficit (Handa et al., 1983; Gomes and Prado, 2007; López et al., 2009). This type of osmotic adjustment under water deficit conditions has been reported in leaves and in other organs of sorghum, rice, potatoes, corn, wheat (Silva et al., 2007), pine (López et al., 2009), and oil palm (Cao et al., 2011).

Finally, taking into account that tolerance to water deficit certainly integrates several traits such as photosynthetic rate, distribution of assimilates among vegetative (roots and bulb reserves) and reproductive organs (bunches), stomatal regulation, rigidity of cellular membrane structures (lipids and proteins), and osmotic adjustment (Cornaire et al., 1994; Silva et al., 2007; Jaleel et al., 2009), these results allow establishing two genotype/environment tolerance relationships that do not rule out hybrids, but place them according to the soil water potential and their best ecophysiological response in terms of high photosynthetic rates, low leaf respiration rate, water potential adjustment, and water use efficiency, as Gomes and Prado (2007) did when working with coconut (Cocus nucifera). Therefore, the relationships are: adequate soil moisture conditions (field capacity) with a tolerance of 'U1859'>'U1937'='U1914'>'U1273'; and moderate and severe water deficit conditions with a tolerance of 'U1937'>'U1914'> 'U1859'>'U1273'. 
In conclusion, the 'U1859' hybrid had a better physiological performance growing under adequate water supply conditions, while the 'U1937' and 'U1914' ones responded successfully to water deficit (moderate and severe). This study is the first step to future research, in which these results could be correlated with another biochemical activity and root development in order to more accurately characterize the comparative tolerance to water deficit.

\section{REFERENCES}

Avendaño C, Molina J, Trejo C, López C, Cadena J (2008) Respuesta a altos niveles de estrés hídrico en maíz. Agr. Mesoam. 19:27-37.

Cao H, Sun C, Sao H, lei T (2011) Effects of low temperature and drought on the physiological and growth changes in oil palm seedlings. Afr. J. Biotechnol. 10:2630-2637.

Cayón G (1998) Ecofisiología de la palma de aceite (Elaeis guineensis Jacq.). In: Primer Curso Internacional de Palma de Aceite. Memorias, Corporación Centro de Investigación en palma de aceite. Santafé de Bogotá, Colombia, pp. 38-54.

Cha S, Takabe T, Kirdmanee C (2010) Osmotic potential, photosynthetic abilities and growth characters of oil palm (Elaeis guineensis Jacq.) seedlings in responses to polyethylene glycol-induced water deficit. Afr. J. Biotechnol. 9:6509-6516.

Corley R, Tinker P (2003) The Oil Palm. 4th ed. Blackwell Science, United Kingdom.

Cornaire B, Daniel C, Lamade E, Fodil Z (1994) Comportamiento de la palma de aceite bajo estrés hídrico. Palmas 15:61-70.

Dubois M, Gilles K, Hamilton J, Rebers P, Smith F (1956) Colorimetric method for determination of sugars and related substances. Anal. Chem. 28:350-356.

García A, Dorado M, Pérez I, Montilla E (2010) Efecto del déficit hídrico sobre la distribución de fotoasimilados en plantas de arroz (Orysa sativa L.). Interciencia 35:47-54.

Gomes F, Oliva M, Mielke M, De Almeida A, Leite H (2006) Photosynthetic irradiance-response in leaves of dwarf coconut palm (Cocos nucifera L. 'nana', Arecaceae): comparison of three models. Sci. Hortic. 109:101-105.

Gomes F, Prado C (2007) Ecophysiology of coconut palm under water stress. Braz. J. Plant Physiol. 19:377-391.

Handa S, Bressan R, Handa A, Carpita N, Hasegawa P (1983) Solutes contributing to osmotic adjustment in cultured plant cells adapted to water stress. Plant Physiol. 73:834-843.

Haniff M (2006) Gas exchange of excised oil palm (Elaeis guineensis) Fronds). Asian J. Plant Sci. 5:09-13.

Henson I (1992) Carbon assimilation, respiration and productivity of young palm (Elaeis guineensis). Elaeis 4:51-59.

Hormaza P, Fuquen E, Romero H (2012) Phenology of the oil palm interspecific hybrid Elaeis oleifera $\times$ Elaeis guineensis. Sci. Agric. 69:275-280.

Jaleel C, Manivannan P, Wahid A, Farooq M, Somasundaram R, Panneerselvam $R$ (2009) Drought stress in plants: a review on morphological characteristics and pigments composition. IJAB. 11:100-105.

Kallarackal J, Jeyakumar P, Jacob S (2004) Water use of irrigated oil palm at three different arid locations in Peninsular India. J. Oil Palm Res. 16:45-53.
López R, Aranda I, Gil L (2009) Osmotic adjustment is a significant mechanism of drought resistance in Pinus pinaster and Pinus canariensis. Invest. Agrar. Sist. Rec. For. 18:159-166.

Martínez C, Moreno U (1992) Expresiones fisiológicas de resistencia a la sequia en dos variedades de papa sometidas a estrés hídrico en condiciones de campo. Rev. Bras. Fisiol. Veg. 4:33-38.

Moreno L (2009) Respuesta de las plantas al estrés por déficit hídrico. Una revisión. Agron. Colombiana. 27:179-191.

Nelson N (1944) A photometric adaptation of the Somogyi method for determination of glucose. J. Biol. Chem. 153:257-262.

Nieto A, Troyo E, García J, Murillo B, Ruiz F, Pimienta E (2009) Efecto del estrés hídrico edáfico en emergencia y desarrollo de plántula en las especies de chile (Capsicum frutescens L. y Capsicum annuum L.). Trop. Subtrop. Agroecosyst. 10:405-413.

Peláez E, Ramírez D, Cayón G (2010) Fisiología comparada de palmas africana (Elaeis guineensis Jacq,), americana (Elaeis oleifera H.B.K. Cortes) e híbridos (Elaeis oleifera H.B.K. x Elaeis guineensis Jacq) en Hacienda La Cabaña. Palmas 31:29-38.

Polanía J, Rao I, Beebe S, García R (2009) Desarrollo y distribución de raíces bajo estrés por sequía en fríjol común (Phaseolus vulgaris L.) en un sistema de tubos con suelo. Agr. Colombiana. 27:25-32.

Prieto J, Cornejo E, Domínguez P, Návar J, Marmolejo J, Jiménez J (2004) Estrés hídrico en Pinus engelmannii Carr., producido en vivero. Invest. Agr. Sist. Recur. For. 13:443-451.

Ramachandra A, Viswanatha K, Vivekanandan M (2004) Droughtinduced responses of photosynthesis and antioxidant metabolism in higher plants: A Review. J. Plant Physiol. 161:1189-1202.

Rocha P, Prada F, Rey L, Ayala I (2006) Caracterización bioquímica parcial de la colección de Elaeis oleifera de Cenipalma proveniente de la Amazonía colombiana. Palmas 27:35-44.

Romero H, Ayala I, Ruiz R (2007) Ecofisiología de la palma de aceite. Palmas 28:176-184.

Ryser P (2006) The mysterious root length. Plant Soil 286:1-6.

Silva H, Ortiz M, Acevedo E (2007) Relaciones hídricas y ajuste osmótico en trigo. Agrociencia 41:23-34.

Smith B (1989) The effects of soil water and atmospheric vapour pressure deficit on stomatal behaviour and photosynthesis in the oil palm. J. Exp. Bot. 40:647-651.

Smith B (1993) Correlations between vegetative and yield characteristhics and photosynthetic rate and stomatal conductance in the oil palm (Elaeis guineensis Jacq). Elaeis 5:12-26.

Somogyi M (1952) Notes of sugar determination. J. Biol. Chem. 195:19-23.

Sun C, Cao H, Shao H, Lei X, Xiao Y (2011) Growth and physiological responses to water and nutrient stress in oil palm. Afr. J. Biotechnol. 10:10465-10471.

Torres G, Sarria G, Varon F, Coffey M, Elliot M, Martinez G (2010) First report of bud rot caused by Phytophthora palmivora on African oil palm in Colombia. Plant Dis. 94:1163.

Villalobos E, Umaña C, Sterling F (1990) Determinación del contenido relativo de agua en progenies de palma aceitera (Elaeis guineensis), durante la época seca en Quepos, Costa Rica. Agr. Costarricense. 14:73-8. 